UDC 576.8.097.29

DOI: 10.21668/health.risk/2019.4.15.eng

\title{
ASSESSING SENSITIVITY OF CAMPYLOBACTER JEJUNI TO ANTI-MICROBE EFFECTS TO REDUCE RISKS OF FOOD PRODYCTS CONTAMINATION WITH CAMPYLOBACTERIOSIS AGENTS
}

\author{
N.R. Efimochkina, V.V. Stetsenko, Yu.M. Markova, L.P. Minaeva, I.B. Bykova, \\ T.V. Pichugina, S.A. Sheveleva
}

Federal Research Center for Nutrition, Biotechnology and Food Safety, 2/14 Ust'inskiy proezd, Moscow, 109240, Russian Federation

\begin{abstract}
We aimed to assess efficiency of various anti-microbe effects on pathogenic microflora; to do that, we performed comparative study on how sensitive Campylobacter jejuni test strains were to ultraviolet radiation and biocides based on peracetic acid (PAA). PAA-based biocides suppressed significant numbers of Campylobacter; however, preset treating modes didn't allow achieving complete inactivation of the test strains. Efficiency of effects produced by ultraviolet radiation on C.jejuni strains depended on exposure duration: 20-minute treatment of plates with broth bacterial suspensions caused a decrease in a number of viable cells which was equal to 1.5-2,0 logarithmic orders; 60-minute treatment resulted in a decrease in C.jejuni contents that amounted to less than $200 \mathrm{CFU} / \mathrm{cm}^{3}$.

Polypeptide antibiotics produced by lactic-acid bacteria (bacteriocins, nisin, etc.) have some useful properties and it makes them applicable for suppressing adverse microflora in food products manufacture. We applied an 'associate growth" model to examine peculiarities related to C.jejuni growth in milk that, beside this pathogen, was simultaneously inoculated with mesophilic lactic-acid lactococci or thermophilic lactic-acid bacteria that were bacteriocins producers. Depending on quantity of introduced lactic-acid bacteria, such as Lactobacillusplantarum, Lactobacilluslactis and Lactococcuslactis, C.jejuni growth was substantially inhibited. We revealed a relationship between anti-bacterial activity and nature of inhibiting effects and concentrations of the above-mentioned lactic-acid microorganisms, temperature, an amount of time during mixed cultures were cultivated together, and properties of used strains which became the most apparent when lactobacteria were introduced in a dose equal to $10^{8} \mathrm{CFU} / \mathrm{cm}^{3}$.

Our study on an ability of $C$.jejuni to survive under exposure to an adverse environment revealed that microbe populations had variable physiological properties, Campylobacter were greatly resistant, and it was difficult to make a relevant choice on efficient tools and procedures for anti-microbe treatment.

Key words: Campylobacter jejuni, in vitro model, biocides, anti-microbe effects, ultraviolet radiation, contamination, biofilms, lactic-acid bacteria.
\end{abstract}

Bacteria from Campylobacter stem have considerable epidemiological significance and it makes it necessary to establish whether these microorganisms are able to survive contemporary technological processes in food products manufacturing under exposure to various technogenic or biological factors. It is advisable to examine how bacteria from Campylobacter stem develop their stress tolerance as it allows more efficient assessment of microbiological risks and more efficient monitoring over food products

(C) Efimochkina N.R., Stetsenko V.V., Markova Yu.M., Minaeva L.P., Bykova I.B., Pichugina T.V., Sheveleva S.A., 2019

Natalya R. Efimochkina - Doctor of Biological Sciences., Leading researcher at the Laboratory for Biosafety and Nutrimicrobiome Analysis (e-mail: karlikanova@ion.ru; tel.: +7 (495) 698-53-83; ORCID: http://orcid.org/0000-0002-9071-0326).

Valentina V. Stetsenko - Junior researcher at the Laboratory for Biosafety and Nutrimicrobiome Analysis (e-mail: stetsenko_valentina1992@mail.ru; tel. +7 (495) 698-53-83; ORCID: http://orcid.org/0000-0001-6470-171X).

Yulia M. Markova - Candidate of Biological Sciences, Researcher at the Laboratory for Biosafety and Nutrimicrobiome Analysis (e-mail: yulia.markova.ion@gmail.com; tel.: +7 (495) 698-53-83; ORCID: http://orcid.org/0000-0002-2631-6412).

Liudmila P. Minaeva - Candidate of Technical Sciences, Senior researcher at the Laboratory for Biosafety and Nutrimicrobiome Analysis (e-mail: liuminaeva-ion@mail.ru; tel.: +7 (495) 698-53-83); ORCID: http://orcid.org/0000-0003-1853-5735).

Irina B. Bykova - Researcher at the Laboratory for Biosafety and Nutrimicrobiome Analysis (e-mail: bikova@ion.ru; tel.: +7 (495) 698-53-83; ORCID: https://orcid.org/0000-0001-7288-312X).

Tatiana V. Pichugina - Candidate of Technical Sciences, Researcher at the Laboratory for Biosafety and Nutrimicrobiome Analysis (e-mail: bbtvp@ion.ru; tel.: +7 (495) 698-53-83; ORCID: http://orcid.org/0000-0002-4632-7119).

Svetlana A. Sheveleva - Doctor of Medical Sciences, Head of the Laboratory for Biosafety and Nutrimicrobiome Analysis (e-mail: sheveleva@ion.ru; tel.: +7 (495) 698-53-83; ORCID: https://orcid.org/0000-0001-5647-9709). 
contamination with campylobacteriosis-inducing agents.

Bacteria from Campylobacter stem are widely spread in the environment and can be found on surfaces of any equipment and tools applied at food manufacturing enterprises $[1,2]$. As objects located within production workshops are frequently contaminated with live Campylobacter bacteria, there is a potential hazard that they can be additionally infected due to non-cultivated forms and biofilms occurring under exposure to technological stress factors such as sub-lethal doses of antibiotics, acids, disinfectants, biocides, etc. [2-4]. This process is seen as a mechanism microorganisms apply to adapt and survive in natural and artificial ecosystems [5-7]. Irradiation that is widely used to perform bactericidal treatment of objects at production facilities and packing materials can also stimulate a stress response in bacteria; this response not only induces tolerance in bacteria to such exposure but also make them resistant to other techniques applied to treat raw materials and finished products $[8,9]$.

Influence exerted by adverse environmental factors on vital functions performed within a bacterial cell occurs at various regulatory levels and it can be accompanied with induced tolerance of microorganisms to exposure to these or those bactericidal factors. Bacteria can become tolerant in nature or during sanitary treatment of water or equipment under exposure to different antibacterial agents including chlorine, acids, alkali, preservatives, antioxidants, bacteriophages, colicins, acrylates, and metal ions [10-12].

At present treatment with chlorine-containing substances is quite often used in food production as a tool to decrease contamination with pathogenic microorganisms $[8,9,13,14]$. Free chlorine and substances that evolve it (sodium hypochlorite, calcium hypochlorite, magnesium hypochlorite, chlorinated lime, chloramines, chlorine dioxide, sodium dichloroisocyanurate, and calcium dichloroisocyanurate) have substantial anti-microbe properties and are efficient against most pathogenic bacteria; they are widely used as disinfectants in medicine and veterinary, to treat drinking water and sewage waters, as well as in food production where they are applied to treat equipment and even to reduce microbe contamination on surfaces of raw materials [13-15].

Treatment with chlorine-containing biocides prevents cross contamination of products with infectious agents that cause alimentary infections and toxic infections and allows achieving longer shelf life for food products. However, application of chlorine also produces certain adverse effects such as occurrence of trihalomethanes that are toxic and carcinogenic, for example, chloroform, dichlorobrommethane, di bromchloromethane, and bromoform $[6,13]$. In general, when such compounds are found in residual quantities conforming to maximum permissible levels, it allows avoiding direct health risks such as toxic, allergic or any other reactions when people consume food products that contain such residual quantities. However, at present it is proven that potentially microorganisms that contaminate food and drinks can have both acquired lower sensitivity to biocides and co-resistance to anti-microbe preparations $[10,16]$. Experts also think that biocides application can have several negative consequences, for example, making bacterial pathogens evolve faster and causing occurrence of new infections that are hazardous for people $[11,12]$.

These phenomena indicate that remote risks related to application of anti-microbe means in technological processes are somewhat underestimated. Such issues as whether conventional concentrations of biocides applied in food industry are safe or various contaminants becoming tolerant to them as well as changes in phenotypic properties of the most significant microorganisms groups haven't been studied in depths.

To reduce risks caused by the given adverse impacts, it is vital to make a wellsubstantiated choice on efficient and safe tools for decontamination of raw materials and sani- 
tary treatment of equipment used in food manufacturing.

Data and methods. We assessed how efficient various anti-microbe preparation were in terms of suppressing pathogenic microflora; to do that, we comparatively analyzed how sensitive test-strains of Campylobacter and salmonella (bacteria-indicators of food pathogens) were to exposure to biocides based on hypochlorite and technological auxiliary agents "Food Clean Peroxy" and "Kriodez" based on peracetic acid (PAA). We applied a previously developed laboratory model in vitro [17] to determine how sensitive $C$. Jejuni bacteria were to adverse impacts; to do that, we simultaneously cultivated several sub-populations of the examined strains under different parameters of gas medium and incubation regimes. We determined a ratio of viable colony-forming units (CFU) to overall number of cells in a population via calculating genome DNA contents in samples with qualitative real-time PCR [18].

We assessed efficiency of anti-microbe effects produced by active chlorine solutions on salmonella as per occurrence or absence of growing test-strains in dextrose-peptone medium with bromthymol blue indicator after a biocide had been introduced and samples had been cultivated for 18 hours under $37^{\circ} \mathrm{C}$. To vary two factors, namely biocide concentration and bacterial suspension density, we applied 96-well sterile immunologic plates [19]. A medium becoming turbid and changes in its color from blue-green to yellow indicated there was growth. We measured optical density of media with "Sunrise" automated plate spectrophotometer.

We determined C. jejuni strains ability to create biofilms with a previously developed in vitro laboratory model [20]. Strains were cultivated on polystyrene 96- and 24-well plates; we applied Mueller-Hinton broth as a cultivating medium with $5 \%$ defibrinated blood being added into it as well as growth additives "Mersk" and "HiMedia" that contained sodium pyruvate, sodium metabisulfite, and iron sulfate. We determined film creation intensity with chromogenic technique using a plate spectrophotometer.

Obtained results were statistically treated with Student's t-test and Mann-Whitney nonparametric rank test. Discrepancies were considered to be authentic at $\mathrm{P}<0.05$. We made all the calculations with EXCEL and SPSS 18.0 software packages.

Results. We assessed inhibiting effects produced by disinfectants as per intensity of test strains growth depending on biocides concentrations and bacterial population density (Table 1).

Figure 1 shows assessment of effects produced by active chlorine on salmonella in a chromogenic model in vitro.

"Kriodez" had weaker effects on campylobacter in comparison with "Food Clean Peroxy" and its application resulted in a fall in test-strains quantity that was equal only to 1-2 logarithmic orders (from $1.0 \times 10^{9} \mathrm{CFU} / \mathrm{cm}^{3}$ to $1.0 \times 10^{7-8} \mathrm{CFU} / \mathrm{cm}^{3}$ ). Results obtained via our comparative assessment of anti-microbe effects produced by PAA-based biocides prove that it is necessary to optimize modes of contact cooling that are applied to cool raw materials at poultry-processing enterprises; it is also necessary to make relevant selection on working concentrations of disinfectant solutions.

After S.enteritidis and S.typhimurium strains were treated with chlorine, we detected that there was no film-creating whereas C. jejuni tended to have stronger ability to created biofilms (Figure 2).

So, as we concluded, application of chlorine-contained disinfectants didn't provide proper and efficient treatment of substrates contaminated with campylobacter; therefore, we tested other anti-microbe impacts. To do that, we examined how sensitive campylobacter test strains were to UV-radiation as compared with affects produced by PAA-based biocides.

We assessed inhibiting effects produced by bactericidal means as per intensity of test strains growth depending on UV treatment duration and PAA concentration (Table 2). 
Effects produced by biocides on C. jejuni and Salmonella spp.

\begin{tabular}{|c|c|c|c|c|c|c|c|c|c|c|}
\hline \multirow{2}{*}{ Test strains } & \multicolumn{10}{|c|}{ Cultivation of initial test-cultures suspension * } \\
\hline & $10^{-1}$ & $10^{-2}$ & $10^{-3}$ & $10^{-4}$ & $10^{-5}$ & $10^{-6}$ & $10^{-7}$ & $10^{-8}$ & $10^{-9}$ & $10^{-10}$ \\
\hline \multicolumn{11}{|c|}{ Control (without biocides) } \\
\hline Salmonella enteritidis & + & + & + & + & + & + & + & + & + & + \\
\hline Salmonella typhimurium & + & + & + & + & + & + & + & + & + & - \\
\hline C.jejuni $13 \mathrm{p}$ & + & + & + & + & + & + & + & + & + & - \\
\hline C.jejuni 5p & + & + & + & + & + & + & + & + & - & - \\
\hline \multicolumn{11}{|c|}{ Hypochlorite (active chlorine concentration is $50 \mathrm{mg} / \mathrm{dm}^{3}$, exposed for 25 minutes at $+2^{\circ} \mathrm{C}$ ) } \\
\hline Salmonella enteritidis & + & + & + & + & + & - & - & - & - & - \\
\hline Salmonella typhimurium & + & + & - & - & - & - & - & - & - & - \\
\hline C.jejuni $13 \mathrm{p}$ & + & + & + & - & - & - & - & - & - & - \\
\hline C.jejuni 5p & + & + & - & - & - & - & - & - & - & - \\
\hline \multicolumn{11}{|c|}{ "Food Clean Peroxy" $\left(0.04 \%\right.$-solution, exposed for 25 minutes at $\left.+2{ }^{\circ} \mathrm{C}\right)$} \\
\hline Salmonella enteritidis & - & - & - & - & - & - & - & - & - & - \\
\hline Salmonella typhimurium & - & - & - & - & - & - & - & - & - & - \\
\hline C.jejuni $13 \mathrm{p}$ & + & + & + & + & - & - & - & - & - & - \\
\hline C.jejuni 5p & + & + & + & - & - & - & - & - & - & - \\
\hline \multicolumn{11}{|c|}{ "Kriodez" (0.04\%-solution, exposed for 25 minutes at $\left.+2{ }^{\circ} \mathrm{C}\right)$} \\
\hline Salmonella enteritidis & - & - & - & - & - & - & - & - & - & - \\
\hline Salmonella typhimurium & - & - & - & - & - & - & - & - & - & - \\
\hline C.jejuni 13p & + & + & + & + & + & + & + & - & - & - \\
\hline C.jejuni 5p & + & + & + & + & + & + & - & - & - & - \\
\hline
\end{tabular}

Note:

$+/-$ means absence or occurrence of growth in relevant cultivated test-strains suspensions after exposure to a biocide;

* means that initial broth culture contains bacteria in a quantity not less than $1 \times 10^{9} \mathrm{CFU} / \mathrm{cm}^{3}$.

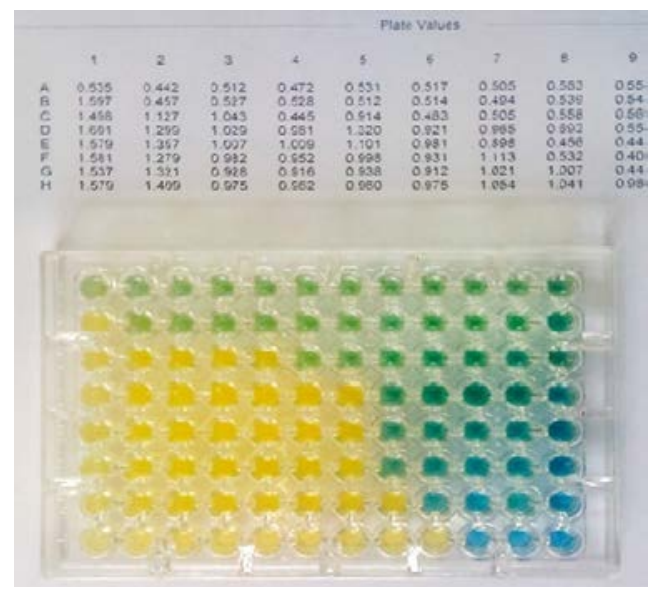

S. enteritidis

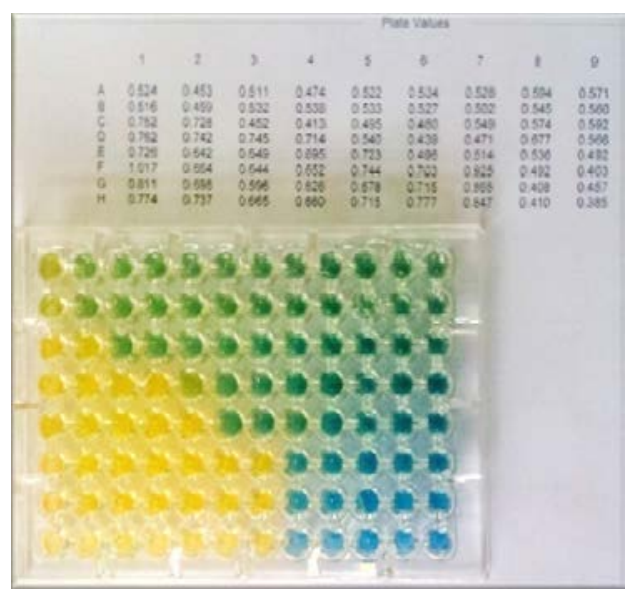

S. typhimurium

Figure 1. Growth in collection salmonella test strains under exposure to active chlorine within concentrations range equal to $10-200 \mathrm{mg} / \mathrm{dm}^{3}$ in an experimental chromogenic model 


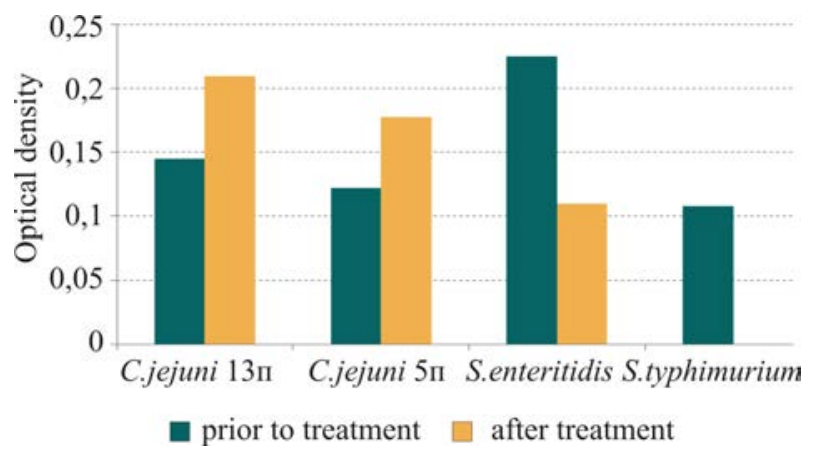

Figure 2. Ability of campylobacter and salmonella strains to form biofilms

PAA-based biocides with working solution concentration being equal to $0.04 \%$ inhibited a considerable number of $C$.jejuni bacteria (from $10^{6.5-8}$ to $10^{2-3} \mathrm{CFU} / \mathrm{cm}^{3}$ ); however, preset treatment modes didn't make test-strains completely inactive. Efficiency of impacts exerted by UV-radiation on campylobacter strains depended on exposure dura-

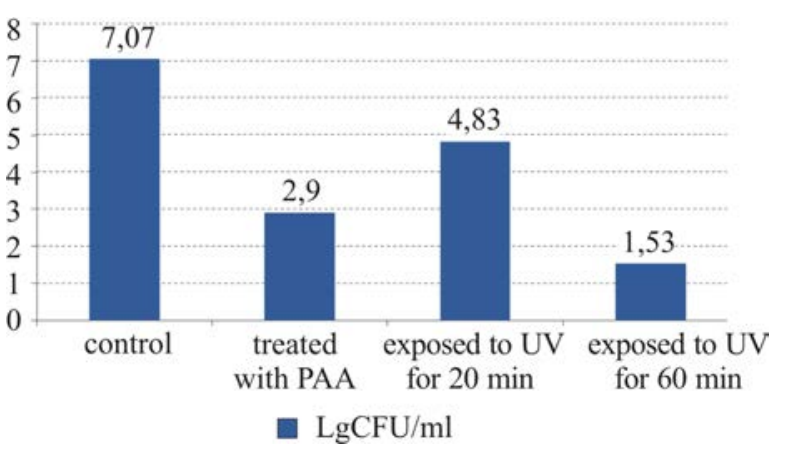

Figure 3. Bactericidal impacts on C.jejuni survival

tion; after plates with broth bacterial suspension were treated for 20 minutes, quantity of viable cells went down by $1.5-2$ logarithmic orders from their initial concentration which was equal to $10^{7}-10^{8} \mathrm{CFU} / \mathrm{cm}^{3}$; after 60 -minute treatment C.jejuni concentration decreased drastically and amounted to less than $200 \mathrm{CFU} / \mathrm{cm}^{3}$ (Figure 3).

Table 2

Growth of C.jejuni strains under exposure to different anti-microbe impacts

\begin{tabular}{|c|c|c|c|c|c|}
\hline \multirow[b]{2}{*}{ Determined parameters } & \multicolumn{4}{|c|}{ Number of strains / repetitions } & \multirow[b]{2}{*}{$\begin{array}{l}\text { Mean values, } \\
M \pm m \text { (test) }\end{array}$} \\
\hline & $\begin{array}{l}\text { NCTC 11,168 } \\
\text { (control) } n=3\end{array}$ & $\begin{array}{c}17 \mathrm{p} \\
n=3\end{array}$ & $\begin{array}{c}23 \mathrm{p} \\
n=3\end{array}$ & $\begin{array}{c}5.2 \\
n=3\end{array}$ & \\
\hline \multicolumn{6}{|c|}{ Test strains cultivation at $+37^{\circ} \mathrm{C}$ under microaerophilic conditions (control) } \\
\hline $\begin{array}{l}\text { Bacterial suspension density, } 1 \mathrm{~g} \\
\mathrm{CFU} / \mathrm{cm}^{3}\end{array}$ & 7.99 & 6.9 & 6.8 & 6.6 & $7.07 \pm 0.31$ \\
\hline $\mathrm{PCR}$ results / $(\mathrm{Ct})$ & $\begin{array}{c}+ \\
(14.5)\end{array}$ & $\begin{array}{c}+ \\
(14.8)\end{array}$ & $\begin{array}{c}+ \\
(17.5)\end{array}$ & $\begin{array}{c}+ \\
(16.3)\end{array}$ & $(15.78 \pm 0.7)$ \\
\hline \multicolumn{6}{|c|}{ Treatment with PAA $\left(0.04 \%\right.$-solution, exposed for $25 \mathrm{~min}$ at $\left.+2^{\circ} \mathrm{C}\right)$} \\
\hline $\begin{array}{l}\text { Bacterial suspension density, lg } \\
\mathrm{CFU} / \mathrm{cm}^{3}\end{array}$ & 3.6 & 2.6 & 2.1 & 3.3 & $2.90 \pm 0.34$ \\
\hline $\mathrm{PCR}$ results / $(\mathrm{Ct})$ & $\begin{array}{c}+ \\
(21.6) \\
\end{array}$ & $\begin{array}{c}+ \\
(17.3) \\
\end{array}$ & $\begin{array}{c}+ \\
(23.1) \\
\end{array}$ & $\begin{array}{c}+ \\
(21.0) \\
\end{array}$ & $(20.75 \pm 1.2)$ \\
\hline $\begin{array}{l}\text { Inhibition, lg orders from initial } \\
\text { level }\end{array}$ & 4.4 & 4.3 & 4.7 & 3.3 & 4.1 \\
\hline \multicolumn{6}{|c|}{ Exposed to UV-radiation for $20 \mathrm{~min}$} \\
\hline $\begin{array}{l}\text { Bacterial suspension density, } 1 \mathrm{~g} \\
\mathrm{CFU} / \mathrm{cm}^{3}\end{array}$ & 4.3 & 5.6 & 5.1 & 4.3 & $4.83 \pm 0.32$ \\
\hline $\mathrm{PCR}$ results / $(\mathrm{Ct})$ & $\begin{array}{c}+ \\
(28.8)\end{array}$ & $\begin{array}{c}+ \\
(29.8)\end{array}$ & $\begin{array}{c}+ \\
(28.6)\end{array}$ & $(32.7)$ & $(29.07 \pm 0.37)$ \\
\hline $\begin{array}{l}\text { Inhibition, lg orders from initial } \\
\text { level }\end{array}$ & 3.7 & 2.3 & 1.7 & 2.3 & 2.1 \\
\hline \multicolumn{6}{|c|}{ Exposed to UV-radiation for $60 \mathrm{~min}$} \\
\hline $\begin{array}{l}\text { Bacterial suspension density, } \mathrm{lg} \\
\mathrm{CFU} / \mathrm{cm}^{3}\end{array}$ & 1.9 & 2.1 & 1.1 & $<1.0$ & $1.53 \pm 0.28$ \\
\hline $\mathrm{PCR}$ results / $(\mathrm{Ct})$ & $\begin{array}{c}+ \\
(29.0) \\
\end{array}$ & $\begin{array}{c}+ \\
(26.2) \\
\end{array}$ & $\begin{array}{c}+ \\
(27.1) \\
\end{array}$ & $\begin{array}{c}+ \\
(30.7) \\
\end{array}$ & $\begin{array}{c}+ \\
(28.25 \pm 1.0) \\
\end{array}$ \\
\hline $\begin{array}{l}\text { Inhibition, lg orders from initial } \\
\text { level }\end{array}$ & 6.09 & 4.8 & 5.7 & 5.6 & 5.4 \\
\hline
\end{tabular}


Table 3

Detection of $C$.jejuni during souring of experimentally contaminated raw milk

\begin{tabular}{|c|c|c|c|c|c|c|c|}
\hline \multirow{3}{*}{$\begin{array}{l}\text { Lactic-acid } \\
\text { microorganisms }\end{array}$} & \multirow{3}{*}{$\begin{array}{c}\text { Lactic-acid } \\
\text { microorganisms } \\
\text { concentration, cells } / \mathrm{cm}^{3}\end{array}$} & \multicolumn{6}{|c|}{ C.jejuni concentration, cells $/ \mathrm{cm}^{3}$} \\
\hline & & \multicolumn{2}{|c|}{$10^{2}$} & \multicolumn{2}{|c|}{$10^{3}$} & \multicolumn{2}{|c|}{$10^{4}$} \\
\hline & & $6 \mathrm{~h}$ & $24 \mathrm{~h}$ & $6 \mathrm{~h}$ & $24 \mathrm{~h}$ & $6 \mathrm{~h}$ & $24 \mathrm{~h}$ \\
\hline \multirow{3}{*}{ Lactobacillusplantarum } & $10^{4}$ & + & - & + & + & + & + \\
\hline & $10^{6}$ & - & - & + & + & + & + \\
\hline & $10^{8}$ & - & - & - & - & + & - \\
\hline \multirow{3}{*}{ Lactobacilluslactis } & $10^{4}$ & - & - & + & - & + & + \\
\hline & $10^{6}$ & - & - & + & - & + & + \\
\hline & $10^{8}$ & - & - & - & - & + & - \\
\hline \multirow{3}{*}{ Lactococcuslactis } & $10^{4}$ & + & - & + & + & + & + \\
\hline & $10^{6}$ & - & - & + & - & + & + \\
\hline & $10^{8}$ & - & - & - & - & - & - \\
\hline
\end{tabular}

Note: “+” means C.jejuni grow , “-” means $C$.jejuni don’t grow.

We performed comparative examinations aimed at assessing anti-microbe impacts on bacteria from Campylobacter stem; the results indicate it is necessary to select up-to-date and more efficient means for decontaminating industrial environment at food-making productions.

Available data on impacts exerted by physical, chemical, and biological factors on bacteria from Campylobacter stem stimulated research on abilities possessed by certain microorganisms, namely their ability to demonstrate symbiotic or antagonistic properties within complicated biocenosis with food pathogens. The greatest attention here is paid to lactic-acid bacteria with apparent anti-microbe effects and substances extracted from them. Antagonism that lactic-acid bacteria seem to have is predominantly explained by specific antibiotic substances with polypeptide essence; these substances can produce certain anti-microbe effects and have different chemical structure. Bacteriostatics produced by lactic-acid bacteria (bacteriocin, nisin, etc.) have a set of benign features and it gives an opportunity to use them for inhibiting adverse microflora in food production.

Data on interactions between campylobacter and lactic-acid microorganisms are scarce due to difficulties related to simulating a natural microbial background of this complicated biotechnological process in experimental conditions. A model of "associated growth" was applied to examine peculiarities of C.jejuni reproduction in milk that was, in addition to this pathogen, simultaneously inoculated with either mesophilic lactic-acid lactococcus or thermophilic lactobacillus. Campylobacter reproduction was inhibited considerably depending on a quantity of lactic-acid bacteria introduced into a culture and incubation temperature (Table 3).

Anti-bacterial impacts exerted by Lactobacillusplantarum cultures were similar to those produced by bacteriocin; they were detected in experiments in vitro, but $C$. jejuni bacteria didn't die, that is, the effect was only bacteriostatic. Growth of pathogenic campylobacter strains was also detected when they were cultivated in milk together with Lactobacilluslactis and lactic-acid lactococcus Lactococcuslactis. C. Jejuni were inactivated after 6-24 hours of incubating in mixed populations as their initial level dropped by $1-3 \mathrm{lg}$. Anti-bacterial activity and essence of inhibiting effects were established to depend on concentrations of the above-mentioned lactic-acid microorganisms, temperature, a pe- 
riod during which mixed cultures were cultivated, and properties of used strains which became the most apparent when lactic-acid bacteria were introduced in a dose equal to $10^{8} \mathrm{CFU} / \mathrm{cm}^{3}$.

Studies on C. Jejuni ability to survive under adverse environmental exposure revealed that physiological properties of microbe populations were variable and bacteria from Campylobacter stem were highly resistant; therefore, it was difficult to select relevant and efficient means and procedures for anti-microbe treatment. So any further research should concentrate on transferrable resistance of bacteria from Campylobacter stem and influence exerted on their survival and transfer into noncultivated forms by stress factors in industrial environment; it is also important to examine specific mechanisms of phenotypic adaptation (tolerance) to sub-lethal concentrations of antimicrobe agents.

Conclusion. General protective properties possessed by Campylobacterspp. can become apparent via different interactions between bacteria and the environment thus making for occurrence of resistant microorganisms both in vitro and in real industrial conditions under exposure to stress technogenic or biological factors.

The most apparent trend in changes that occur in C. jejuni properties is an increase in their resistance to bactericidal effects caused by wide use of anti-microbe preparations (AMP), including antibiotics and biocides.

A model of "associated growth" was applied to show dependence between antibacterial activity and inhibiting effects and concentrations of lactic-acid bacteria

Lactobacillusplantarum, Lactobacilluslactis and Lactococcuslactis, temperature, a period during which mixed cultures were cultivated, and properties of used strains that became the most apparent when lacticacid bacteria were introduced in a dose equal to $10^{8} \mathrm{CFU} / \mathrm{cm}^{3}$.

To assess efficiency of impacts exerted by pathogenic microflora by various anti-microbe means, we conducted a comparative study on how sensitive campylobacter test-strains were to UV-radiation and PAA-based biocides. PAA-based biocides inhibited a considerable number of C.jejuni bacteria; however, preset treatment modes didn't make test-strains completely inactive. Efficiency of impacts exerted by UV-radiation on campylobacter strains depended on exposure duration and anti-microbe exposure conditions.

Funding. The research was granted financial support by the Russian scientific fund (Project No. 15-16-00015).

Conflict of interests. The authors declare there is no any conflict of interests.

\section{References}

1. Guerin M.T., Sir C., Sargeant J.M., Waddell L., O'Connor A.M., Wills R.W., Bailey R.H., Byrd J.A. The change in prevalence of Campylobacter on chicken cascasses during processing: A systematic review. Poult. Sci., 2010, vol. 89, no. 5, pp. 1070-1084. DOI: 10.3382/ps.2009-00213

2. Yang H., Li Y., Johnson M.G. Survival and death of Salmonella typhimurium and Campylobacter jejuni in processing water and on chicken skin during poultry scalding and chilling. J. Food Prot, 2001, vol. 64, no. 6, pp. 770-776. DOI: 10.4315/0362-028x-64.6.770

3. Vidal A.B., Davies R.H., Rodgers J.D., Ridley A., Clifton-Hadley F. Epidemiology and Control of Campylobacter in Modern Broiler Production. Campylobacter Ecology and Evolution. Norfolk, UK, Caister Academic Press Publ., 2014, vol. 1, pp. 287-231.

4. Teh A.H., Lee S.M., Dykes G.A. Does Campylobacter jejuni form biofilms in food-related environment? Appl. Environ. Microbiol, 2014, vol. 80, no. 17, pp. 5154-5160. DOI: 10.1128/AEM.01493-14

5. An Evaluation of EPA's Proposed Guidelines for Carcinogen Risk Assessment Using Chloroform and Dichloroacetate as Case Studies. Report of an Expert Panel. International Life Sciences 
Institute, 1997. Available at: https://hesiglobal.org/publication/an-evaluation-of-epas-proposedguidelines-for-carcinogen-risk-assessment-using-chloroform-and-dichloroacetate-as-case-studiesworkshop-report/ (20.07.2019).

6. Christian M.S., York R.G., Hoberman A.M., Fisher L.C., Brown W.R. Oral (drinking water) two-generation reproductive toxicity study of bromodichloromethane (BDCM) in rats. International Journal of Toxicology, 2002, vol. 21, no. 2, pp. 115-146. DOI: 10.1080/10915810252866097

7. Hicks S.J., Rowbury R.J. Resistance of attached Escherichia coli to acrylic acid and its significance for the survival of plasmid-bearing organisms in water. Ann. Inst. Pasteur, 1987, vol. 138, no. 3, pp. 359-369. DOI: 10.1016/0769-2609(87)90124-4

8. Scientific Opinion of the Panel on Biological Hazards on a request from DG SANCO on the assessment of the possible effect of the four antimicrobial treatment substances on the emergence of antimicrobial resistance. The EFSA Journal, 2008, no. 659, pp. 1-26.

9. Mohyla P., Bilgili S.F., Oyarzabal O.A., Warf C.C., Kemp G.K. Application of Acidified Sodium Chlorite in the Drinking Water to Control Salmonella serotype Typhimurium and Campylobacter jejuni in Commercial Broilers. J. Appl. Poult Res, 2007, vol. 16, no. 1, pp. 45-51. DOI: 10.1093/japr/16.1.45

10. Nikaido H. Multidrug resistance in bacteria. Annu Rev. Biochem, 2009, no. 78, pp. 119146. DOI: $10.1146 /$ annurev.biochem.78.082907.145923

11. European Food Safety Authority and European Centre for Disease Prevention and Control. The European Union summary report on antimicrobial resistance in zoonotic and indicator bacteria from humans, animals and food in 2014. EFSA Journal, 2016, vol. 14, no. 2, 270 p. DOI: $10.2903 /$ j.efsa. 2018.5182

12. Mavri A., Ribič U., Možina S.S. The Biocide and Antibiotic Resistance in Campylobacter jejuni and Campylobacter coli. Emerging and Traditional Technologies for Safe, Healthy and Quality Food, 2015, pp. 269-283. DOI: 10.1007/978-3-319-24040-4_15

13. Christian M.S., York R.G., Hoberman A.M., Diener R.M., Fisher L.C., Gates G.A. Biodisposition of dibromoacetic acid (DBA) and bromodichloromethane (BDCM) administered to rats and rabbits in drinking water during range-finding reproduction and developmental toxicity studies. International Journal of Toxicology, 2001, vol. 20, no. 4, pp. 239-253.

14. Rao M.V. Acidified Sodium Chlorite (ASC). Chemical and Technical Assessment. Prepared for the 68th the Joint FAO/WHO Expert Committee on Food Additives. JECFA, 2007, 12 p. Available at: http://www.fao.org/fileadmin/templates/agns/pdf/jecfa/cta/68/Acidified_Sodium_Chlorite.pdf (20.07.2019).

15. Oyarzabal O.A. Reduction of Campylobacter spp. by commercial antimicrobials applied during the processing of broiler chickens: a review from the United States perspective. J. Food Prot, 2005, vol. 68, pp. 1752-1760. DOI: 10.4315/0362-028x-68.8.1752

16. The global view of campylobacteriosis: report of an expert consultation, Utrecht, Netherlands, 9-11 July 2012. World Health Organization, 2013, 69 p. Available at: https://apps.who.int/ iris/handle/10665/80751 (20.07.2019).

17. Stetsenko V.V., Efimochkina N.R., Pichugina T.V. Osobennosti rosta i persistentsii Campylobacter jejuni v pishchevykh produktakh [Peculiarities of Campylobacter jejuni growth and persistence in food products]. Byulleten' eksperimental'noi biologii i meditsiny, 2018, vol. 166, no. 12, pp. 723-730 (in Russian).

18. Efimochkina N.R., Stetsenko V.V., Bykova I.B., Polyanina A.S., Aleshkina A.S., Sheveleva S.A. Osobennosti kul'tivirovaniya i khraneniya bakterii roda Campylobacter v usloviyakh in vitro [Peculiarities of cultivating and storing Campylobacter bacteria in in vitro conditions]. Byulleten' eksperimental'noi biologii i meditsiny, 2017, vol. 164, no. 7, pp. 81-88 (in Russian).

19. Efimochkina N.R., Bykova I.B., Korotkevich Yu.V., Markova Yu.M., Minaeva L.P., Sheveleva S.A. Study of tolerance of enterobacteria to chlorine-based biocides in experimental models using chromogenic indicator tests. Health Risk Analysis, 2015, no. 3, pp. 73-82 (in Russian). DOI: $10.21668 /$ health.risk/2015.3.11.eng 
20. Efimochkina N.R., Bykova I.B., Markova Yu.M., Korotkevich Yu.V., Stetsenko V.V., Minaeva L.P., Sheveleva S.A. Formirovanie bioplenok pishchevymi patogenami i razrabotka na ikh osnove laboratornoi modeli in vitro dlya issledovaniya bakterii roda Campylobacter [Food pathogens forming biofilms and an in vitro laboratory model based on such films and applied to examine bacteria from Campylobacter family]. Byulleten' eksperimental'noi biologii i meditsiny, 2016, vol. 162, no. 10, pp. 470-475 (in Russian).

Efimochkina N.R., Stetsenko V.V., Markova Yu.M., Minaeva L.P., Bykova I.B., Pichugina T.V., Sheveleva S.A. Assessing sensitivity of campylobacter jejuni to anti-microbe effects to reduce risks of food prodycts contamination with campylobacteriosis agents. Health Risk Analysis, 2019, no. 4, pp. 139-147. DOI: 10.21668/health.risk/2019.4.15.eng

Received: 25.07.2019

Accepted: 13.12.2019

Published: 30.12.2019 